\title{
STUDY ON THE EFFECT OF NATURAL BACKGROUND FOR GAMMA SPECTROMETER SYSTEM
}

\author{
Tran Thien Thanh ${ }^{(1)}$, Chau Van Tao ${ }^{(1)}$, Hoang Duc Tam ${ }^{(2)}$, Vo Thi Hong Yen ${ }^{(3)}$ \\ (1) University of Science, VNU-HCM; \\ (2) Ho Chi Minh City University of Pedagogy; (3) Can Tho University \\ (Received March 21 $1^{\text {th }}$, 2011, Accepted April 13 $\left.{ }^{\text {rd }}, 2012\right)$
}

ABSTRACT: In the analysis of environmental radioactive isotopes using gamma spectrometry, natural background radiation is an important parameter related to the analytical results directly. Therefore, in this work, the influence of natural background radiation was studied for two models: with and without shielding of gamma spectrometer system. The initial results showed that the minimum detectable activity (MDA) of radionuclides such as ${ }^{234} \mathrm{Th},{ }^{226} \mathrm{Ra},{ }^{212} \mathrm{~Pb},{ }^{208} \mathrm{Tl},{ }^{40} \mathrm{~K},{ }^{214} \mathrm{~Pb},{ }^{214} \mathrm{Bi},{ }^{228} \mathrm{Ac}$ have the difference of two models from $10 \%$ to $503 \%$. This is the basis for researches to improve the lead shielding chamber in the future.

Keyword: background, lead shielding, gamma spectrometer system

\section{INTRODUCTION}

Environmental background radiation affects to critical limit $\left(\mathrm{L}_{\mathrm{C}}\right)$ of detectors, the lower background radiation the higher sensitivity of detector. For making low background radiation, it's necessary to test the origin of background radiation and then find out methods for decreasing an undesired contribution of background radiation. Besides, to measure the radioactivity of environmental sample exactly, the activity of radionuclides of environmental background radiation is as low as possible. Environmental background radiation has the natural origin and they emit mainly from ${ }^{235} \mathrm{U}$, ${ }^{238} \mathrm{U},{ }^{232} \mathrm{Th}$ (and their daughters) and ${ }^{40} \mathrm{~K}$ radionuclides. When they get the radioactivity equilibrium, radioactivity of ${ }^{238} \mathrm{U}$ and ${ }^{232} \mathrm{Th}$ radionuclides can be calculated through the radioactivity of their daughters. Decay diagrams of ${ }^{238} \mathrm{U}$ and ${ }^{232} \mathrm{Th}$ chains are showed in Fig. 1 (1a and 1b).

Therefore, to decrease the influence of environmental background radiation on counting sample, both of measured sample and detector are put inside the lead shielding chamber. In this work, we will study the influence of natural background radiation in two experimental setups: with and without shielding of the gamma spectrometer system.

\section{Trang 16}




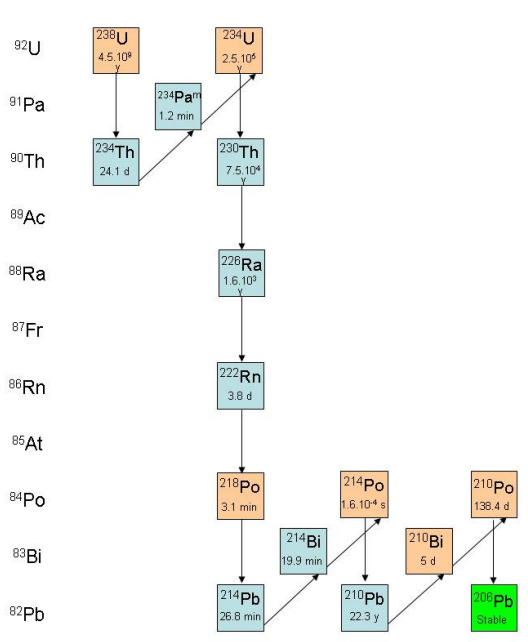

Fig. 1a.Decay diagram of ${ }^{238} \mathrm{U}$ chain

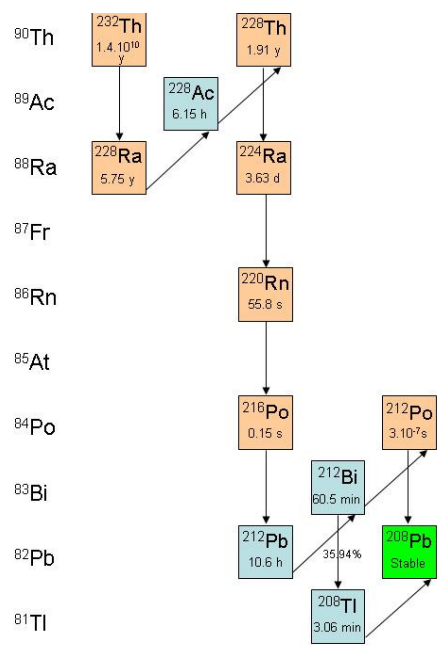

Fig. 1b. Decay diagram of ${ }^{232}$ Th chain

range of interested peaks and background, respectively.

- Minimum Detectable Activity (MDA)

MDA is the minimum value of activity of radionuclides in which the hyper germanium (HPGe) spectrometer system can measure the gamma rays emitting from sample with given reliability, given by the following formula:

$$
\operatorname{MDA}=\frac{\mathrm{L}_{\mathrm{D}}}{\varepsilon_{\mathrm{p}} \cdot \mathrm{I}_{\gamma} \cdot \mathrm{t} \cdot \mathrm{m}}
$$

Where MDA, $\mathrm{L}_{\mathrm{D}}, \varepsilon_{\mathrm{P}}, \mathrm{I}_{\gamma}, \mathrm{t}$ and $\mathrm{m}$ are minimum detectable activity $(\mathrm{Bq} / \mathrm{kg})$, detection limit, full energy peak efficiency, gamma-ray emission probability, acquisition time (s) and sample mass $(\mathrm{kg})$, respectively.

\section{MATERIAL AND METHODS}

\section{Germanium Spectrometer System}

Low background spectrometer system includes HPGe detector that it is put inside lead 
shielding chamber and connected with electrical instruments. Gamma-rays emitting from radionuclides of sample will be measured by HPGe detector. Signals are amplified preliminarily when they go through preamplifier and then will be amplified at amplifier. Finally, they will be showed on display as gamma energy spectrum.

\section{Detector}

The gamma-ray spectra were measured with a spectrometer based on a p-type coaxial HPGe semiconductor detector (G2018) with aluminium window and side cap. The performance and geometry of detector are shown in Table 1

Table 1.The parameters of HPGe detector

\begin{tabular}{|c|c|c|}
\hline \multicolumn{2}{|c|}{ Relative efficiency } & $22.4 \%$ \\
\hline \multicolumn{2}{|c|}{ Energy resolution (FWHM) at $1332 \mathrm{keV}\left({ }^{60} \mathrm{Co}\right)$} & $1.76 \mathrm{keV}$ \\
\hline \multicolumn{2}{|c|}{ Peak-to-Compton ratio } & 55:1 \\
\hline \multirow{9}{*}{$\begin{array}{l}\text { Geometrical } \\
\text { parameters } \\
\text { of the detector }\end{array}$} & Window thickness & $1.5 \mathrm{~mm}$ \\
\hline & Crystal-window distance & $5.0 \mathrm{~mm}$ \\
\hline & Crystal dead layer thickness & $0.86 \mathrm{~mm}$ \\
\hline & Crystal length & $49.5 \mathrm{~mm}$ \\
\hline & Crystal diameter & $52.0 \mathrm{~mm}$ \\
\hline & Crystal hole depth & $35.0 \mathrm{~mm}$ \\
\hline & Crystal hole diameter & $7.0 \mathrm{~mm}$ \\
\hline & Side cap thickness & $1.5 \mathrm{~mm}$ \\
\hline & Side cap diameter (external) & $76.2 \mathrm{~mm}$ \\
\hline
\end{tabular}

\section{Lead shielding}

Lead is the kind of material with high $\mathrm{Z}$, so it can reduce the background radiation inside the lead shielding chamber. However, the interaction between gamma-rays and lead material is origin of the appearance X-rays in low energy range. Therefore, we used $1 \mathrm{~mm}$ layer of tin and $1.5 \mathrm{~mm}$ layer of copper and put them inside lead shielding chamber in order to absorb these X-rays.

Structure of lead shielding chamber and technical parameters are showed in Fig. 2.

\section{Trang 18}




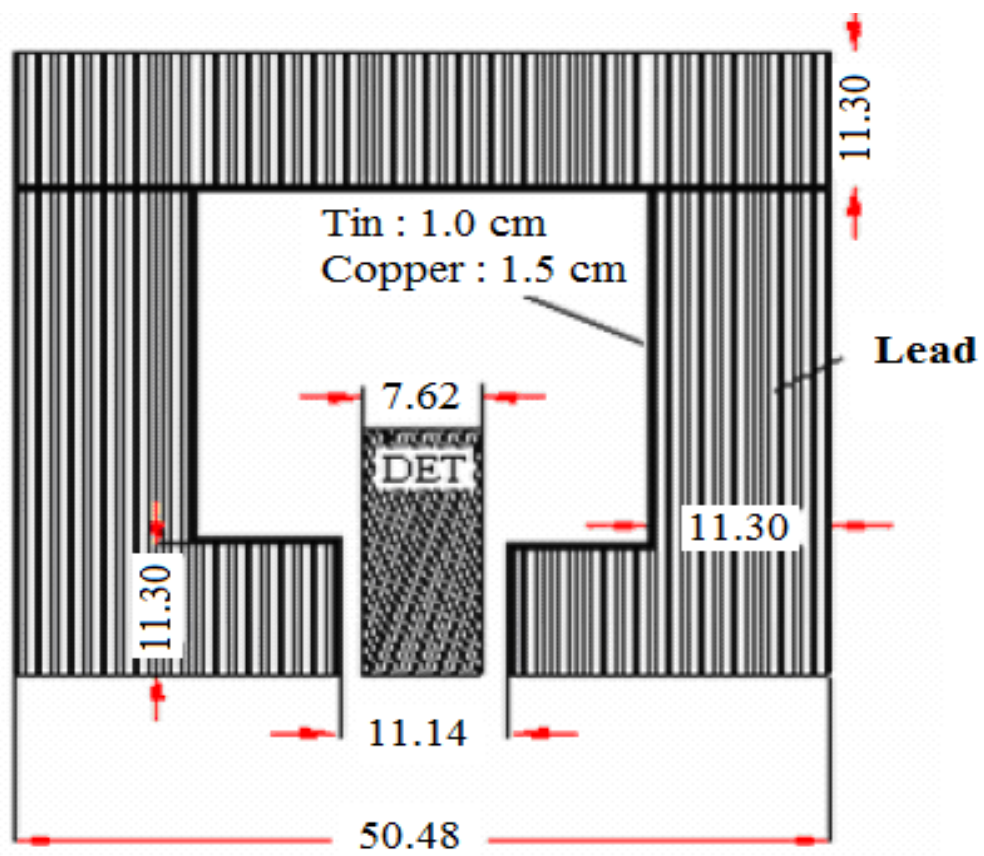

Fig. 2.Cross-section view of detector-shield setup (unit of centimeter)

\section{Efficiency Calibration}

In this work, we use the RGU standard sample to form the curve of efficiency versus energy. Specific activity of RGU is $4940 \pm 30$ $\mathrm{Bq} / \mathrm{kg}$. RGU sample is packed in the cylindrical container $(4.7 \mathrm{~cm}$ x $7.5 \mathrm{~cm}$ diam.). The container was sealed with adhesive tape and left for at least 4 weeks (7 haft-lives of ${ }^{222} \mathrm{Rn}$ ) before counting by gamma spectrometry in order to ensure that daughter products of ${ }^{226} \mathrm{Ra}$ up to ${ }^{210} \mathrm{~Pb}$ achieve equilibrium with their parent radionuclides, respectively.

A general efficiency curve (efficiency versus energy) was obtained by fitting a $\log -\log$ polynomial function to experimental values obtained using RGU sample.

$$
\log (\varepsilon(E))=\sum_{i=0}^{6} a_{i}(\log (E))^{i}
$$

Where, $\varepsilon(E), E$ and $a_{i}$ are efficiency of detector to full energy peaks, energy and fitting parameters, respectively.

\section{RESULTS AND DISCUSSION}

In this experimental setup, open-top lead shielding is compared with close-top lead shielding. Fig. 3 shows gamma spectrum with time acquisition of 3 days (259200 seconds) in two experiments: with and without shielding. 


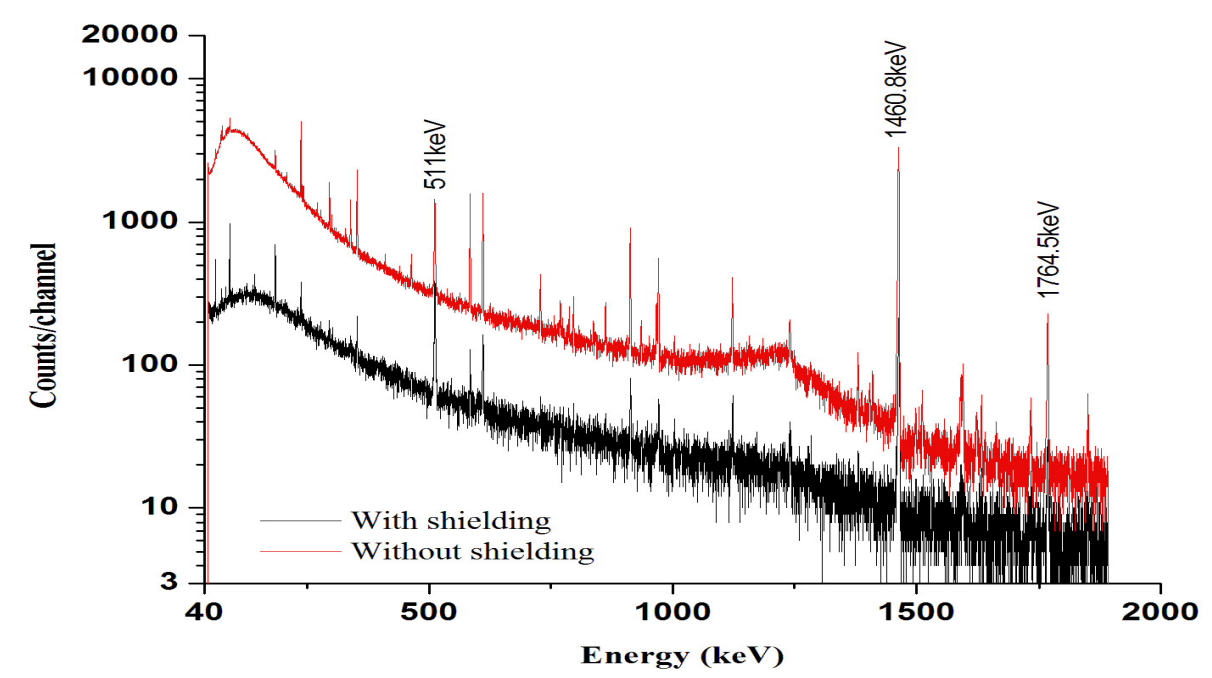

Fig 3. Spectrum of environmental background radiation: with and without shielding

Table 2. Efficiency of detector to full energy peak in range from $63.3 \mathrm{keV}$ to $1764.5 \mathrm{keV}$

\begin{tabular}{|c|c|c|c|c|}
\hline Nuclide & Energy (keV) & Net Area & Efficiency $(\varepsilon)$ & Relative uncertainty \\
\hline${ }^{234} \mathrm{Th}$ & 63.3 & 41345 & 0.00015631 & 3.97 \\
\hline${ }^{234} \mathrm{Th}$ & 92.8 & 95384 & 0.00062896 & 3.72 \\
\hline${ }^{226} \mathrm{Ra}$ & 186.2 & 105744 & 0.00042170 & 3.69 \\
\hline${ }^{214} \mathrm{~Pb}$ & 241.9 & 172555 & 0.00033659 & 3.69 \\
\hline${ }^{214} \mathrm{~Pb}$ & 295.2 & 370093 & 0.00028494 & 3.68 \\
\hline${ }^{214} \mathrm{~Pb}$ & 351.9 & 628919 & 0.00025046 & 3.68 \\
\hline${ }^{214} \mathrm{Bi}$ & 609.3 & 435522 & 0.00013573 & 3.68 \\
\hline${ }^{214} \mathrm{Bi}$ & 665.4 & 12157 & 0.00011265 & 4.08 \\
\hline${ }^{214} \mathrm{~Pb}$ & 785.9 & 9510 & 0.00012671 & 4.25 \\
\hline${ }^{214} \mathrm{Bi}$ & 806.1 & 9290 & 0.00010436 & 4.27 \\
\hline${ }^{214} \mathrm{Bi}$ & 806.1 & 9290 & 0.00010436 & 4.27 \\
\hline${ }^{214} \mathrm{Bi}$ & 1120.3 & 87344 & 0.00008305 & 3.69 \\
\hline${ }^{214} \mathrm{Bi}$ & 1238.4 & 31387 & 0.00007631 & 3.74 \\
\hline${ }^{214} \mathrm{Bi}$ & 1377.9 & 22276 & 0.00007959 & 3.79 \\
\hline${ }^{214} \mathrm{Bi}$ & 1401.5 & 6579 & 0.00007013 & 4.14 \\
\hline${ }^{214} \mathrm{Bi}$ & 1407.9 & 11431 & 0.00006784 & 3.91 \\
\hline${ }^{214} \mathrm{Bi}$ & 1509.2 & 9956 & 0.00006633 & 4.08 \\
\hline${ }^{214} \mathrm{Bi}$ & 1661.3 & 4614 & 0.00006242 & 4.42 \\
\hline${ }^{214} \mathrm{Bi}$ & 1729.6 & 14465 & 0.00007211 & 3.81 \\
\hline${ }^{214} \mathrm{Bi}$ & 1764.5 & 68694 & 0.00006361 & 3.70 \\
\hline
\end{tabular}

\section{Trang 20}




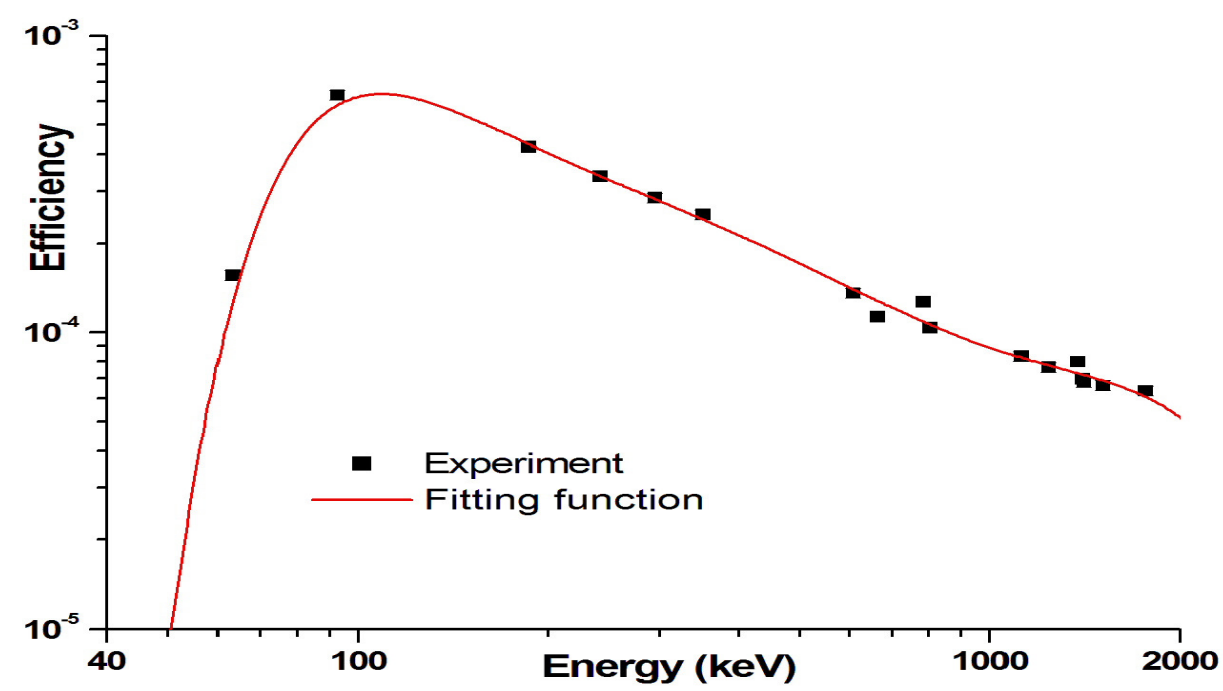

Fig 4. The curve of efficiency of detector to cylindrical sample used in the experiment

Finally, using formula (3), we determined MDA of the radionuclides in ${ }^{238} \mathrm{U},{ }^{232} \mathrm{Th}$ and ${ }^{40} \mathrm{~K}$ chains in two cases: with and without shielding. The results are shown in Table 3 and Fig. 5.

Table 3. The values of MDA of radionuclides in the two cases: with and without shielding.

\begin{tabular}{|c|c|c|c|c|}
\hline Nuclide & Energy (keV) & $\begin{array}{c}\text { MDA(Bq/kg) } \\
\text { With shielding } \\
3 \text { days (1) }\end{array}$ & $\begin{array}{c}\text { MDA (Bq/kg) } \\
\text { Without shielding } \\
3 \text { days (2) }\end{array}$ & $\begin{array}{c}\text { Ratio } \\
(2) /(1)\end{array}$ \\
\hline${ }^{234} \mathrm{Th}$ & 63.3 & 1780.84 & 1948.62 & 1.09 \\
\hline${ }^{226} \mathrm{Ra}$ & 186.6 & 38.93 & 58.98 & 1.52 \\
\hline${ }^{212} \mathrm{~Pb}$ & 238.6 & 3.44 & 40.27 & 4.15 \\
\hline${ }^{228} \mathrm{Ac}$ & 338.3 & 8.86 & 20.67 & 4.61 \\
\hline${ }^{214} \mathrm{~Pb}$ & 351.9 & 4.46 & 26.52 & 4.64 \\
\hline${ }^{214} \mathrm{~Pb}$ & 295.2 & 6.07 & 13.08 & 5.03 \\
\hline${ }^{208} \mathrm{Tl}$ & 583.2 & 2.60 & 26.39 & 3.04 \\
\hline${ }^{214} \mathrm{Bi}$ & 609.3 & 8.69 & 64.75 & 2.30 \\
\hline${ }^{214} \mathrm{Bi}$ & 1120.3 & 28.12 & 52.58 & 3.43 \\
\hline${ }^{228} \mathrm{Ac}$ & 911.2 & 15.32 & 410.96 & 3.76 \\
\hline${ }^{40} \mathrm{~K}$ & 1460.8 & 109.41 & & \\
\hline
\end{tabular}




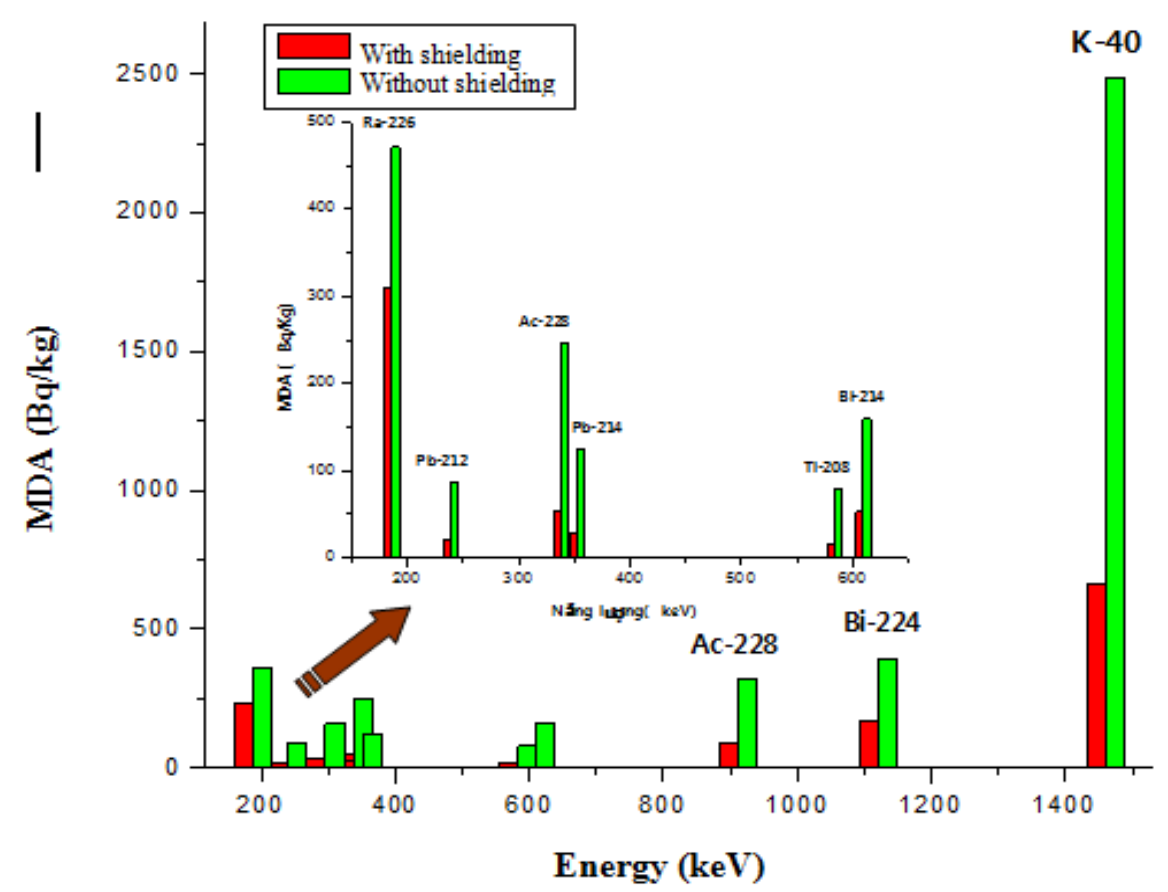

Fig 5. The comparison of MDA for radionuclides of ${ }^{238} \mathrm{U}$ and ${ }^{232} \mathrm{Th}$ chains in two experiments: with and without shielding.

From the data in Table 3 , it is showed that MDA of the radionuclides in the environmental background with shielding is lower from 1.09 to 5.03 times than that of without shielding, significantly daughter radionuclides of radon in two ${ }^{238} \mathrm{U}$ and ${ }^{232} \mathrm{Th}$ chains. Therefore, decreasing the contribution of the environmental background radiation (with shielding) helps us to determine easily the radionuclides in the measured samples. Besides, with shielding, it will also decrease the environmental background radiation in low energy range. This also helps us to determine easily the radionuclides emitting gamma rays in low energy range.

\section{CONCLUSION}

This is the basis for researches to improve lead shielding chamber by adding lead and copper layers into the chamber in order to reduce background radiation to increase $L_{D}$ as well as to reduce MDA in the low energy range in the future.

\section{Trang 22}




\title{
NGHIÊN CưU ẢNH HƯởNG CỦA PHÔNG ĐỐI VỚI Hệ PHỔ KẾ GAMMA
}

\author{
Trần Thiện Thanh ${ }^{(1)}$, Châu Văn Tạo ${ }^{(1)}$, Hoàng Đức Tâm ${ }^{(2)}$, Võ Thị Hồng Yến ${ }^{(3)}$ \\ (1)Trường Đại học Khoa học Tự nhiên, ĐHQG-HCM \\ (2) Trường Đại học Sư phạm Tp. HCM; (3) Đại học Cần Thơ
}

TÓM TÁT: Nghiên cứ đồng vị phóng xạ trong môi truờng sử dụng hệ phổ kế gamma thì phông búc xạ tự nhiên là một tham số quan trọng liên quan trục tiếp đến kết quả phận tích. Vì vậy, trong công trình này, ảnh huởng của phông bức xạ tự nhiên được nghiên cứu cho hai mô hình có che chắn và không che chắn của hệ phổ kế gamma. Kết quả buơớc đầu đã chỉ ra rằng hoạt độ nhỏ nhất mà hệ phổ kế gamma phông thấp sủ dụng đầu dò HPGe có thể phát hiện được (MDA) đối với các đồng vị phóng xạ ${ }_{n h u}{ }^{234} \mathrm{Th},{ }^{226} \mathrm{Ra},{ }^{212} \mathrm{~Pb},{ }^{228} \mathrm{Ac},{ }^{214} \mathrm{~Pb},{ }^{208} \mathrm{Tl},{ }^{214} \mathrm{Bi}$ vă ${ }^{40} \mathrm{~K}$ theo hai mô hình có che chắn và không che chắn có độ sai biệt tù $10 \%$ đến $503 \%$. Đây là cor sở cho việc nghiên cứu để cải tiến hệ buồng chì che chắn trong tuong lai.

Tù khóa: phông, buồng chì che chắn, hệ phổ kế gamma.

\section{REFERENCES}

[1]. R. Gordon, Gilmore, Practical Gammaray Spectrometry, $2^{\text {nd }}$ Edition, Nuclear Training Services Ltd Warrington, UK (2008).

[2]. E. M. El Afifi, M. A. Hilal, S. M. Khalifa, H. F. Aly, Evaluation of $U, T h$, $K$ and emanated radon in some NORM and TENORM samples, Radiation measurements, 41, 627-633 (2005).

[3]. T. P. Dũng, C. V. Tạo, N. H. Dương, Phuoong pháp ghi bức xa ion hóa, NXB Đại học Quốc Gia TP, Hồ Chí Minh (2005).

[4]. http://www.nuclide.org. 